\title{
Database for electronic schedule for patients of psychological clinic
}

\section{Base de datos para agenda electrónica para pacientes de clínica psicológica}

CORTÉS-GARCÍA, Alicia*†, SANTOS-OSORIO, Rene and PERALTA-HERNÁNDEZ, Guillermo

Universidad Tecnológica de San Juan del Río

ID $1^{\text {st }}$ Author: Alicia, Cortés-García / ORC ID: 0000-0003-1044-9787, Researcher ID Thomson: G-5779-2019, CVU CONACYT ID: 671816

ID $1^{\text {st }}$ Coauthor: Rene, Santos-Osorio / ORC ID: 0000-0002-4411-7628, Researcher ID Thomson: G-3453-2019, CVU CONACYT ID: 619722

ID $2^{\text {nd }}$ Coauthor: Guillermo, Peralta-Hernández / ORC ID: 0000-0001-5396-7176

DOI: 10.35429/JEDT.2019.4.3.1.6

Received March 28, 2019; Accepted June 20, 2019

\begin{abstract}
This paper presents the development of an application for the management of patients of a psychological clinic through an online database. Nowadays, the use of technology is expanding more and more, integrating itself in different aspects of society, both in everyday life and in the workplace and industry. Businesses that do not apply new technologies or update themselves run the risk of falling behind competitors or exit the market completely. To implement these technologies, such as software, desktop applications, mobile or internet integration, it is not always necessary to invest many resources or hire new personnel to maintain new equipment. With the simple installation of a computer equipment or implementation of a specialized software, business profits can be maximized or ease the workload. The methodology to be used is: 1. Creation of a desktop application based on Java. 2. Integration of the application with online database. This project seeks to update the way the PSM Psychological Clinic stores and organizes the data of its patients.
\end{abstract}

\section{Desktop application, Database, Learning of IT}

\begin{abstract}
Resumen
En este trabajo se presenta el desarrollo de una aplicación para la gestión de pacientes de una clínica psicológica, con una base de datos en línea. Hoy en día, el uso de tecnología se amplía más y más, integrándose en los diferentes aspectos de la sociedad, tanto en la vida cotidiana como en ámbito laboral e industrial. Los negocios que no apliquen las nuevas tecnologías o se actualicen, corren el riesgo de quedarse atrás de competidores que adaptaron nuevas tecnologías o de salir por completo del mercado. Para implementar estas tecnologías, software, aplicaciones de escritorio, móvil o integración del internet, no es siempre necesario invertir muchos recursos o contratar nuevo personal para el mantenimiento de nuevo equipo. Con la simple instalación de un equipo de cómputo o implementación de un software especializado se puede maximizar las utilidades del negocio o facilitar la carga de trabajo de una forma evidente. La metodología a utilizar será en cascada. Con este proyecto se busca la actualización en la forma en que la Clínica Psicológica PSM guarda y organiza los datos de sus pacientes.
\end{abstract}

Aplicación, Base de datos, Aprendizaje de las TI

Citation: CORTÉS-GARCÍA, Alicia, SANTOS-OSORIO, Rene and PERALTA-HERNÁNDEZ, Guillermo. Database for electronic schedule for patients of psychological clinic. Journal-Economic Development Technological Chance and Growth. 2019. 3-4: 1-6.

\footnotetext{
* Correspondence to Author (email: acortesg@utsjr.edu.mx)

$\uparrow$ Researcher contributing first author.
} 


\section{Introduction}

This article proposes a solution for the management of patients in a psychological clinic with a remote database. In this way, it is intended to contribute to other companies of the same field so that they have a basis to develop their computer systems.

At the time of starting this project, the company still used physical means, that is, paper and pen, to register its clients and patients, having to use a large amount of energy and resources in the management of these records.

As physical means, the records require space to be stored, with the possibility of getting lost or overlapped with the records of other patients, as well as having to search manually if personnel want to review them. The clinic only uses computers to record the sessions of some patients, but these notes have little in common, being as such individual documents.

With this application, not only will psychologists be able to register all patients on a single platform, thus eliminating the use of physical methods for registration, but also all notes, reports and patient sessions will be under one platform, facilitating its creation, use and search in general. steps:

The methodology included the following

1. Research and proposal of programming languages.

2. Analysis of the proposed languages and choosing the most suitable for the project.

3. Development of a desktop application.

4. Integration of the application with online database.

5. Tests

6. Results.

Java

Java is a general-purpose, concurrent, objectoriented programming language that was specifically designed to have as few implementation dependencies as possible.
Its intention is to allow application developers to write the program once and execute it on any device (known as WORA, or "write once, run anywhere"), which means that the code that is executed on a platform does not have to be recompiled to run in another. Java is, as of 2012, one of the most popular programming languages in use, particularly for client-web server applications, with about 10 million users reported. (ictea, 2019)

The Java programming language was originally developed by James Gosling of Sun Microsystems (which was acquired by the Oracle company) and published in 1995 as a fundamental component of the Java Sun Microsystems platform. Its syntax derives largely from $\mathrm{C}$ and $\mathrm{C}++$, but it has fewer lowlevel utilities than any of them. Java applications are generally compiled to bytecode (Java class) that can be run on any Java virtual machine (JVM) regardless of the underlying computer architecture. (The Computer Magazine, 2015).

Java syntax is largely derived from $\mathrm{C}++$. But unlike this one, which combines the syntax for generic, structured and object-oriented programming, Java was built from the beginning to be completely object-oriented. Everything in Java is an object (with some exceptions), and everything in Java resides in some class (remember that a class is a mold from which several objects can be created).

Swing is the library for the advanced graphical user interface of the Java SE platform. The import instructions tell the Java compiler that the javax.swing package classes and interfaces are included in the compilation.

Java libraries are the result of compiling the source code developed by who implements the JRE and offers support for Java development. Some examples of these libraries are:

The central libraries, which include:

- A collection of libraries to implement data structures such as lists, arrays, trees and sets.

- $\quad$ Libraries for XML analysis.

- Security.

- Internationalization and location libraries. 
Integration libraries, which allow communication with external systems. These libraries include:

- $\quad$ The API for accessing JDBC databases (Java DataBase Connectivity).

- $\quad$ The JNDI (Java Naming and Directory Interface) for directory services.

- $\quad$ RMI (Remote Method Invocation) and CORBA for the development of distributed applications.

- Libraries for the user interface, which include:

- $\quad$ The AWT (Abstract Window Toolkit) native toolset, which offers GUI (Graphical User Interface) components, mechanisms for using them and managing their associated events.

- $\quad$ Swing Libraries, built on AWT but offer non-native implementations of AWT components.

- $\quad$ APIs for audio capture, processing and playback.

An implementation dependent on the platform on which the Java virtual machine (JVM) runs, which is responsible for the execution of the code of libraries and external applications.

\section{phpMyAdmin}

It is a tool written in PHP with the intention of managing the administration of MySQL through web pages, using a web browser. It can create and delete databases; create, delete and alter tables; delete, edit and add fields; execute any SQL statement; manage keys in fields; manage privileges; and export data in various formats. (phpadmin, s.f.)

\section{MySQL}

MySQL is the most popular open source database in the world. Despite its powerful features, MySQL is easy to configure and use. MySQL is widely used in web applications, such as Joomla, Wordpress, Drupal or phpBB, on platforms (Linux/Windows-Apache-MySQLPHP/Perl/Python), and by error tracking tools such as Bugzilla. Its popularity as a web application is closely linked to PHP, which often appears in combination with MySQL.
MySQL is a very fast reading database when it uses the MyISAM non-transactional engine, but it can cause integrity problems in high concurrency environments in the modification. In web applications, there is low concurrency in the modification of data and, instead, the environment is intensive reading data, which makes MySQL ideal for this type of applications. Regardless of the environment in which MySQL is used, it is important to monitor performance in advance to detect and correct both SQL and programming errors. (MySQL, s.f.)

Features:

- $\quad$ Large subset of the SQL language. Some extensions are also included.

- Availability in a large number of platforms and systems.

- Possibility of selecting storage mechanisms that offer different operating speeds, physical support, capacity, geographical distribution, transactions...

- Transactions and foreign keys.

- Secure connectivity.

- Replication.

- $\quad$ Search and indexing of text fields.

- $\quad$ Standard: Standard MySQL binaries are recommended for most users, and include the InnoDB storage engine.

- Max (This is not MaxDB, which is a cooperation with SAP): Binaries include additional features that have not been sufficiently tested or that are not normally necessary.

- MySQL-Debug: They are binaries that have been compiled with extra debugging information. It should not be used in production systems because debug code can reduce performance. MySQL is the most popular open source database in the world. Despite its powerful features, MySQL is easy to configure and use.

MySQL is widely used in web applications, such as Joomla, Wordpress, Drupal or phpBB, on platforms (Linux/Windows-Apache-MySQL-

PHP/Perl/Python), and by error tracking tools such as Bugzilla. Its popularity as a web application is closely linked to PHP, which often appears in combination with MySQL. 
MySQL is a very fast reading database when you use the MyISAM nontransactional engine, but it can cause integrity problems in high concurrency environments in the modification. In web applications there is low concurrency in the modification of data and instead the environment is intensive in reading data, which makes MySQL ideal for this type of applications. Whatever the environment in which you are going to use MySQL, it is important to monitor performance in advance to detect and correct both SQL and programming errors. (MySQL, s.f.)

\section{Features:}

- $\quad$ Large subset of the SQL language. Some extensions are also included.

- Availability in a large number of platforms and systems.

- Possibility of selecting storage mechanisms that offer different operating speeds, physical support, capacity, geographical distribution, transactions...

- $\quad$ Transactions and foreign keys.

- $\quad$ Secure connectivity.

- $\quad$ Replication.

- $\quad$ Search and indexing of text fields.

- $\quad$ Standard: Standard MySQL binaries are recommended for most users, and include the InnoDB storage engine.

- Max (This is not MaxDB, which is a cooperation with SAP): Binaries include additional features that have not been sufficiently tested or that are not normally necessary.

- MySQL-Debug: They are binaries that have been compiled with extra debugging information. It should not be used in production systems because debug code can reduce performance.

\section{Choice of language and MDB.}

Due to the benefits and capacity mentioned above with Java, it is the language chosen for the development of this project. The $\mathrm{C}$ and $\mathrm{C}++$ languages, as we have seen, are also good, with the only difference that we do not need to interact with hardware, so it would be a feature that is not necessary in this project.
As DB handler we have chosen MySql for its security and ability to type SQL instructions. It is also very widespread on the net, so is easy to find a good service.

Being the DB on an online server, the clinic avoids having a server within the company; it is also cheaper to hire a server only for the management of the DB than a whole web server.

\section{Development}

The system must enter a patient with full profile, photo and complete their file with multiple sessions and images, and then delete all records by only removing the patient, starting with the empty database (Figure 1), so the application does not return any registered patient (Figure 2).

id nom ape exp edad hon dir tel cel edo ocu med tx sus foto

Figura 1 Base de Datos vacía

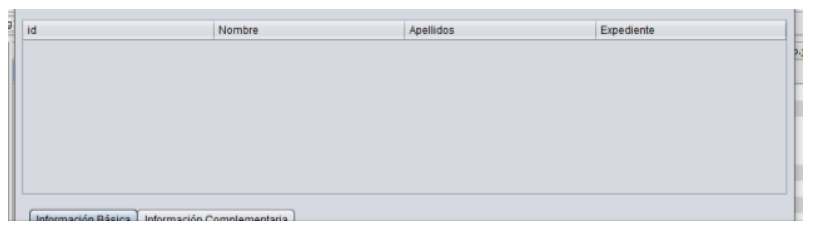

Figura 2 Tabla de Pacientes vacía

The registration of a new patient was successfully created on the Registration screen (Figure 3 and Figure 4), causing the new registration to be on the table of the Patient Consultation screen (Figure 5).

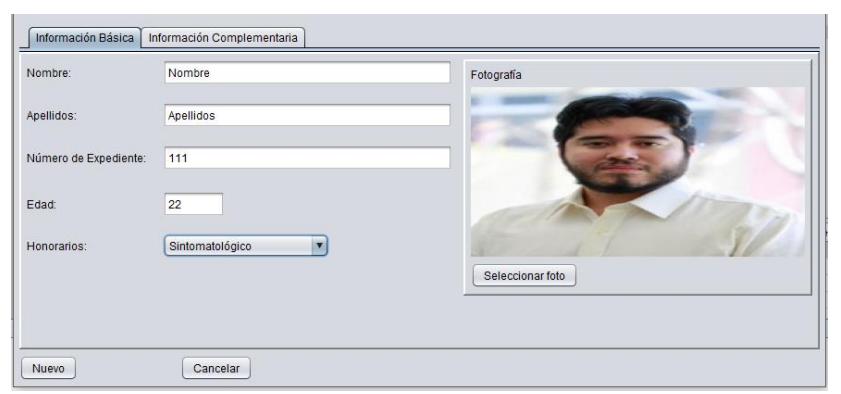

Figura 3 Registro de nuevo Paciente

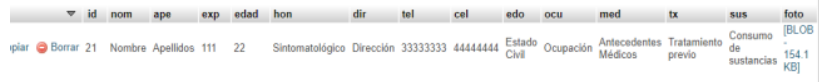

Figura 4 Base de Datos con el nuevo registro 


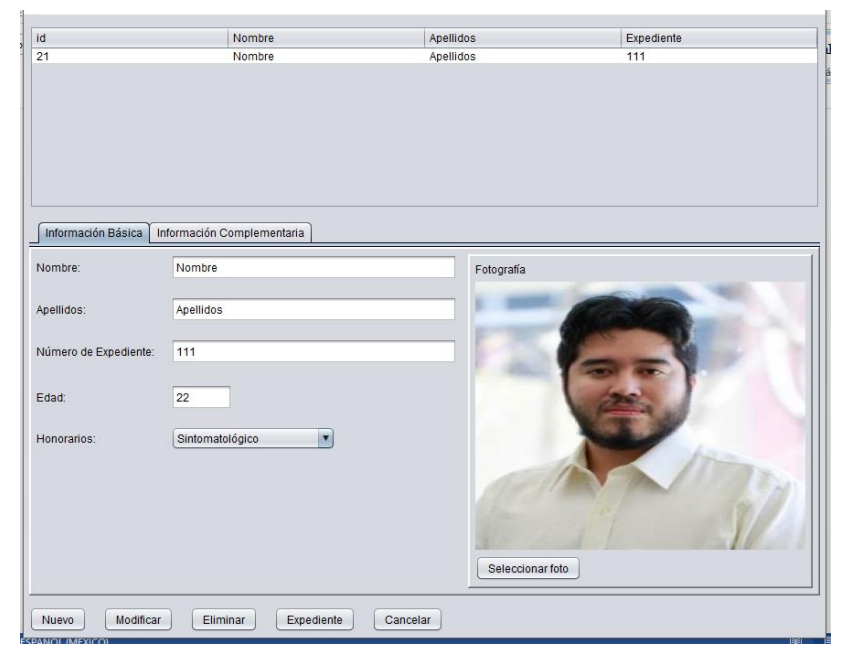

Figura 5 Nuevo Paciente en Consulta

Once the new patient has been selected in the Consultation table (Figure 6), the option to enter File is activated. Once inside, Patient Filiation Data was created (Figure 6), and some fields were subsequently modified to verify the use of the option to modify data (Figure 7).

$\nabla$ idpac pre sin man lat dx

Figura 6 Registro de Datos de Filiación

$\begin{array}{lrlllll}\nabla & \text { idpac } & \text { pre } & \sin & \text { man } & \text { lat } & \text { dx } \\ \text { rrar } & 21 & \text { Pre entrevista } & \text { Síntomas } & \text { Motivo manifiesto } & \text { Motivo latente } & \text { Diagnóstico }\end{array}$

Figura 7 Modificación de Datos de Filiación

Subsequently, new sessions were created for the patient, creating two new sessions, and modifying the data of the first one (Figure 8 and Figure 9). Therefore, both sessions are linked to the same patient identification number. And to end the introduction of records, a couple of images were also added, only to demonstrate that it is possible to add images to the database (Figure 10).

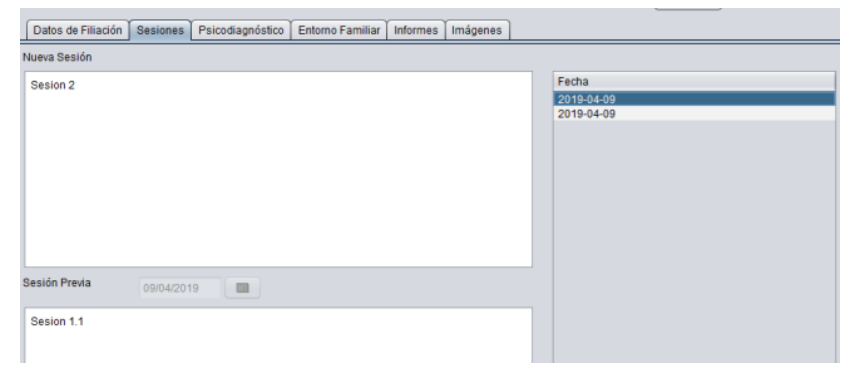

Figura 8 Creación de sesiones

\begin{tabular}{lrllr}
$\nabla$ & idpac & sesion & \multicolumn{1}{l}{ dates } & idses \\
ar & 21 & Sesion 1.1 & $2019-04-09$ & 10 \\
ar & 21 & Sesion 2 & $2019-04-09$ & 11
\end{tabular}

Figura 9 Base de Datos de Sesiones

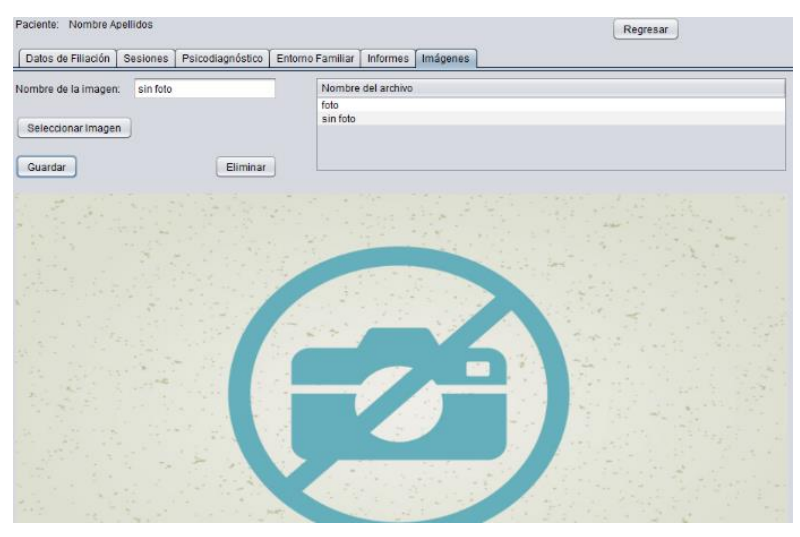

Figura 10 Registro de Imágenes

Once the registration was completed, it was removed from the consultation screen, selecting the patient to be deleted. In response, a dialog screen is activated to confirm the elimination of the patient and all related data (Figure 11).

Once the elimination of the patient is confirmed, all of the data and related records are removed from the database, in this example, the database is empty (Figure 12), as is the session database, since both records are related to the same patient (Figure 13), ending the test successfully.

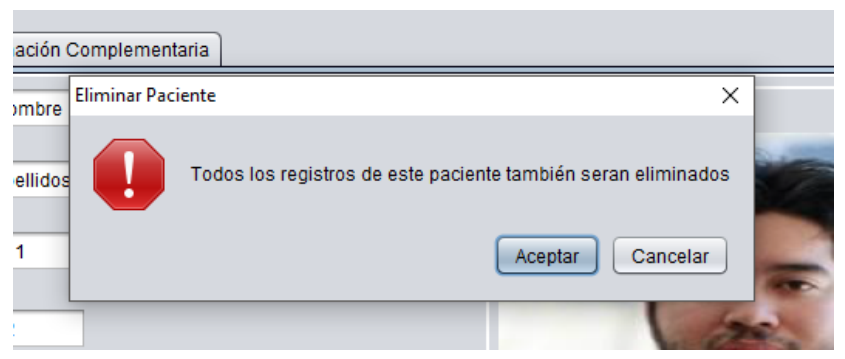

Figura 11 Confirmación para eliminar paciente

id nom ape exp edad hon dir tel cel edo ocu med tx sus foto

Figura 12 Base de Datos después de eliminar al paciente idpac sesion dates idses

Fiagura 13 Base de Datos de Sesiones después de eliminar al Paciente

CORTÉS-GARCÍA, Alicia, SANTOS-OSORIO, Rene and PERALTAHERNÁNDEZ, Guillermo. Database for electronic schedule for patients of psychological clinic. Journal-Economic Development Technological Chance and Growth. 2019 


\section{Conclusions}

The integration of technology into everyday life and work environments is of utmost importance with each passing day, not only for its convenience, but for the help technology provides to achieve our goals in a more efficient way, giving us the opportunity to do much more than what we initially planned.

We have perceived a great change in the way the psychological clinic organizes information, considering the saving of space to store papers, thus avoiding misplacement.

The software is currently in operation and it has been proven that software development with Java and remote MySql for companies with these characteristics is a good option.

\section{References}

(2019). Tecnología móvil como herramienta potencial en la investigación sobre estigma asociado al VIH/SIDA entre estudiantes de medicina.Revista Puertorriqueña de Psicología, 30(1), 60-68.

Barberán, T. J. C., \& Sánchez, H. S. A. C. (2019). LA EDUCACIÓN FAMILIAR EN EL TRATAMIENTO DE CASOS DE ADICCIONES AL ALCOHOL Y OTRAS DROGAS. Revista Cognosis. ISSN 2588-0578, 4(5), 67-82.

Caro-Sabido, E. A., \& Larrosa-Haro, A. (2019). Eficacia de la intervención nutricia y de la actividad física en niños y adolescentes con hígado graso no alcohólico asociado a obesidad: revisión sistemática exploratoria. Revista de Gastroenterología de México.

Encalada, A. S., Molina, J. V., Santander, C. M., Santander, D. M., Chávez, C. V., Espinoza, K. B., ... \& Méndez, R. Y. (2019). Síndrome metabólico, estado nutricional y su relación con diferentes profesiones. Revista Latinoamericana de Hipertension, 14(2), 219-223.

Grandi, F., Burgueño, L., \& Irurtia, M. J. (2019). Eficacia del programa de reducción del estrés basado en mindfulness para cuidadores familiares de personas con demencia. Revisión sistemática de estudios clínicos aleatorizados.Revista Española de Geriatría y Gerontología, 54(2), 109-115. ictea. (marzo de 2019). ictea. Retrieved from: http://www.ictea.com/cs/knowledgebase.php?ac tion $=$ displayarticle $\&$ id $=8790$

La Revista informática. (2015). Retrieved from La Revista informática: http://www.larevistainformatica.com/Java.htm

MySQL. (s.f.). Retrieved from https://www.mysql.com

phpadmin. $\quad$ (s.f.). Retrieved from https://www.phpmyadmin.net

Rivera-Díaz, M., Varas-Díaz, N., ReyesEstrada, M., Coriano, D., Ortiz, N., \& Padilla, M. 